Фармацевтична технологія, біофармація, гомеопатія

Pharmaceutical technology, biopharmacy, homeopathy

Рекомендована д. фрармац. наук, профр. Д. І. Дмитрієвський

УДК 615.453.6.014.2

DOI 10.11603/2312-0967.2016.4.7114

\title{
ПІДБІР КІЛЬКІСНОГО СКЛАДУ ДОПОМІЖНИХ РЕЧОВИН ПРИ СТВОРЕННІ ТАБЛЕТОК «АНГІОЛІН»
}

\author{
(C) І. А. Мазур ${ }^{1,2}$, Л. І. Кучеренко, ${ }^{1,2}$, О. С. Бідненко ${ }^{1}$, Г. І. Ткаченко, \\ Запорізький державний медичний університет ${ }^{1}$ \\ НВО «Фарматрон»², Запоріжжя
}

Резюме: статтю присвячено підбору кількісного складу допоміжних речовин із метою створення таблеток «Ангіолін» методом вологої грануляції. Вивчено вплив п'яти кількісних фракторів та за допомогою рівнянь регресії першого порядку встановлений взаємозв'язок між кількісними фракторами та стійкістю до роздавлювання, стиранністю та часом розпадання таблеток «Ангіолін». Запропонований оптимальний склад таблеток «Ангіолін».

Ключові слова: таблетки «Ангіолін», допоміжні речовини, таблетки, волога грануляція, кількісні фрактори.

Вступ. Початок нинішнього тисячоліття ознаменувався значним поширенням серцево-судинних захворювань, що зайняли 1-2 місце в структурі смертності промислово розвинених країн. Лідируюче місце серед причин розвитку серцевої недостатності займає ішемічна хвороба серця і один з її грізних проявів інфраркт міокарда[7].

Також щорічно у світі переносять інсульт близько 6 млн чоловік, з них 4,7 млн помирає. Тому розробка засобів лікування патологій серцево-судинної системи $є$ актуальною проблемою фармації та медицини. Незважаючи на постійні зусилля із оптимізації лікування захворювань центральної нервової та серцево-судинної систем проблема залишається невирішеною. 3 урахуванням зростаючої вартості медичної допомоги, супутніх соціальних проблем актуальна розробка і впровадження нових підходів, методів, схем терапії, що сприяють реальному підвищенню клінічної ефективності проведеної терапії. Важливим елементом вирішення даної комплексної проблеми $\epsilon$ створення нових високоефективних і безпечних лікарських препаратів, застосування яких призводило б до зниження смертності, покращення якості та тривалості життя [3, 5, 9].

«Ангіолін», новий препарат катіонно-аніонної дії ((S)-2,6-діаміногексановой кислоти 3-метил-1,2,4триазоліл-5-тіоацетат), представник метаболітотропних препаратів 3 вираженим впливом на ендотелій судин головного мозку і серця, кардіопротективні властивості якого спрямовані на підвищення виживання кардіоміоцитів в період гострої ішемії міокарда, поліпшення показників ЕКГ. «Ангіолін» було розроблено співробітниками Запорізького державного медичного університету та фрахівцями НВО «Фарматрон» під керівництвом профр. І. А. Мазура [6].

«Ангіолін» планується використовувати в період як гострої IXC, так і в період амбулаторного лікування хворих. Тому нами було обрано як раціональну форму використання - таблетки [6].

У попередніх дослідженнях нами було підібрано оптимальні допоміжні речовини (ДР) для отримання таблеток «Ангіолін» методом вологої грануляції $[1,8$, 10]. Було встановлено, що найкращі результати щодо фрармако-технологічних показників таблеток «Ангіолін» були отримані при використанні як ДР цукрової пудри, мікрокристалічної целюлози (МКЦ) типу бурст, натрію кроскармелози, розчину метилцелюлози (МЦ) марки 15, МКЦ 200 та кальцію стеарату. Відомо, що особливу увагу при отриманні таблеток приділяють кількісному складу ДР, які входять до лікарської фрорми і дозволяють отримувати таблетки, які відповідають фармако-технологічним вимогам, які наведені в ДФУ [2]. Тому метою нашої роботи є підбір кількісного складу ДР при створенні таблеток «Ангіолін» методом вологої грануляції.

Методи дослідження. При дослідженні кількісного співвідношення ДР у складі таблеток «Ангіолін» була використана діюча речовина - субстанція ангіоліна та низка ДР.

Субстанція ангіоліну виробник ДП «Завод хімічних реактивів» м. Харків була отримана з НВО «Фарматрон» за договором про сумісні дослідження. ДР, які використовувалися для таблеток «Ангіолін», є сертифрікованими і вироблені закордоном.

Таблетки були виготовлені на лабораторному обладнанні і підлягали контролю на новітньому та сучасному обладнанні: тестеру для визначення однорідності маси таблеток, тестеру для визначення стиранності таблеток, міцності, часу розпадання.

При створенні оптимального складу таблеток «Ангіолін» було вивчено 5 кількісних фракторів. Перелік кількісних фракторів та їх рівнів наведено в таблиці 1.

ISSN 2312-0967. Фармацевтичний часопис. 2016. № 4 
Фармацевтична технологія, біофармація, гомеопатія Pharmaceutical technology, biopharmacy, homeopathy

Таблиця 1. Фактори та їх рівні, які вивчалися при розробці оптимального складу таблеток «Ангіолін»

\begin{tabular}{|c|c|c|c|}
\hline \multirow[b]{2}{*}{ Фактори } & \multicolumn{3}{|c|}{ Рівні фракторів } \\
\hline & $\begin{array}{c}\text { нижній рівень } \\
\ll-»\end{array}$ & $\begin{array}{c}\text { основний рівень } \\
\ll 0 »\end{array}$ & $\begin{array}{c}\text { верхній рівень } \\
\ll+»\end{array}$ \\
\hline x - кількість цукрової пудри, \% в таблетці & 8 & 12 & 16 \\
\hline x - кількість МКЦ бурст, \% в таблетці & 4 & 6 & 8 \\
\hline х _- кількість натрій кроскармелози, \% в таблетці & 4 & 6 & 8 \\
\hline $\mathrm{x}_{4}-$ концентрація розчину МЦ 15, \% & 2 & 3 & 4 \\
\hline x & 2 & 3 & 4 \\
\hline
\end{tabular}

Планування експерименту здійснювали за алгоритмом, який наведено в монографії «Математичне планування експерименту при проведенні наукових досліджень в фрармації» [4].

Результати й обговорення. При складанні рецептури таблеток кількість кальцію стеарату на стадії опудрення гранул складала 1\%. В тих випадках, коли згідно з планом експерименту (табл. 2) середня маса таблеток «Ангіолін» була меншою 0,32, до необхідної кількості добавляли МКЦ 101, яка раніше показала найкращий результат [1]

Вивчення п'яти кількісних фракторів проводили за допомогою дробного фракторного експерименту типу $2^{5-2}$. Як генеруюче відношення прийняли $\mathrm{x}_{4}=\mathrm{x}_{1} \mathrm{x}_{2} \mathrm{x}_{3}$ i $\mathrm{x}_{5}$ $=\mathrm{x}_{1} \mathrm{x}_{2}$. План експерименту та результати дослідження таблеток «Ангіолін» наведено в таблиці 2.

Взаємозв'язок між вивченими кількісними факторами та фрармако-технологічними показниками таблеток виражали рівняннями регресії першого порядку [4].

При отриманні таблеток «Ангіолін» у всіх серіях дослідів процес пресування проходив добре та зовнішній їх вигляд відповідав щодо однорідності та якості поверхні, тому за цими відгуками $\left(\mathrm{y}_{1}\right.$ і $\left.\mathrm{y}_{2}\right)$ рівнянь регресії не наводимо.
Взаємозв'язок між вивченими фракторами та однорідністю дозування таблеток «Ангіолін» описується наступним рівнянням регресії:

$y_{3}=1,34-0,021 x_{1}-0,213 x_{2}-0,118 x_{3}-0,096 x_{4}+0,066 x_{5}$

Вплив вивчених факторів оцінювали за величиною коефіцієнтів та знаками перед ними. 3 рівняння регресії видно, що із збільшенням кількості МКЦ бурст, натрію кроскармелози та цукрової пудри в складі таблеток «Ангіолін», а також концентрації розчину МЦ 15 однорідність їх маси покращується. При збільшенні кількості МКЦ 200 на стадії опудрення гранул однорідність маси таблеток «Ангіолін» погіршується. Це пов'язано з тим, що МКЦ 200 добре текуча ДР і проходить сепарація порошкової маси в процесі роботи таблеткової машини.

Взаємозв'язок між вивченими фракторами та механічною стійкістю таблеток «Ангіолін» до роздавлювання описується наступним рівнянням регресії: $\mathrm{y}_{4}=71,87+2,77 \mathrm{x}_{1}-4,34 \mathrm{x}_{2}+7,07 \mathrm{x}_{3}+18,6 \mathrm{x}_{4}+12,8 \mathrm{x}_{5}$

Згідно 3 рівнянням регресії, найбільший вплив на стійкість таблеток «Ангіолін» проявляють фрактори $\mathrm{x}_{4}$ i x $_{5}$. Із збільшенням концентрації розчину МЦ 15, який використовували для отримання гранул, та кількості МКЦ 200 на стадії опудрення гранул стійкість таб-

Таблиця 2. Матриця планування на основі дробного фракторного експерименту $2^{5-2}$ та результати дослідження таблеток «Ангіолін»

\begin{tabular}{|c|c|c|c|c|c|c|c|c|c|c|c|}
\hline № & $\mathrm{x}_{1}$ & $\mathrm{x}_{2}$ & $\mathrm{x}_{3}$ & $\mathrm{x}_{4}$ & $\mathrm{x}_{5}$ & $\mathrm{y}_{1}$ & $\mathrm{y}_{2}$ & $\mathrm{y}_{3}$ & $\mathrm{y}_{4}$ & $\mathrm{y}_{5}$ & $\mathrm{y}_{6}$ \\
\hline 1 & - & - & - & - & + & 5 & 5 & 2,27 & 28,6 & 0,06 & 3,15 \\
\hline 2 & + & - & - & + & - & 5 & 5 & 1,82 & 69,1 & 0,03 & 6,25 \\
\hline 3 & - & + & - & + & - & 5 & 5 & 0,78 & 73,7 & 0,17 & 7,34 \\
\hline 4 & + & + & - & - & + & 5 & 5 & 0,98 & 87,8 & 0,17 & 7,86 \\
\hline 5 & - & - & + & + & + & 5 & 5 & 1,02 & 142,2 & 0,41 & 13,25 \\
\hline 6 & + & - & + & - & - & 5 & 5 & 1,12 & 64,8 & 0,03 & 6,50 \\
\hline 7 & - & + & + & - & - & 5 & 5 & 1,39 & 31,9 & 0,13 & 4,15 \\
\hline 8 & + & + & + & + & + & 5 & 5 & 1,37 & 76,9 & 0,12 & 8,45 \\
\hline
\end{tabular}

Примітки: $\mathbf{y}_{1}$-процес пресування таблеток, бали

$\mathrm{y}_{2}-$ зовнішній вигляд таблеток, бали

$\mathrm{y}_{3}$ - однорідність маси таблеток, $\pm \%$;

$\mathrm{y}_{4}-$ міцність таблеток, $\mathrm{H}$;

$\mathrm{y}_{5}$ - стиранність таблеток першої і другої серії дослідів відповідно, \%

$\mathrm{y}_{6}-$ час розпадання таблеток першої і другої серії дослідів відповідно, хв.

ISSN 2312-0967. Pharmaceutical review. 2016. № 4 
Фармацевтична технологія, біофармація, гомеопатія Pharmaceutical technology, biopharmacy, homeopathy

леток «Ангіолін» до роздавлювання суттєво підвищується. Підвищується стійкість до роздавлювання таблеток «Ангіолін» при збільшенні кількості натрію кроскармелози та цукрової пудри в їх складі. Можна зробити висновок, що властивості натрію кроскармелози за впливом на стійкість таблеток до роздавлювання проявляються також залежно від співвідношення інших компонентів. Збільшення кількості МКЦ бурст веде до зменшення стійкості таблеток «Ангіолін» до роздавлювання.

Взаємозв'язок між вивченими фракторами та стиранністю таблеток «Ангіолін» описується наступним рівнянням регресії:

$$
\begin{gathered}
\mathrm{y}_{5}=0,14-0,052 \mathrm{x}_{1}+0,0075 \mathrm{x}_{2}+0,0325 \mathrm{x}_{3}+0,0425 \mathrm{x}_{4}+ \\
0,055 \mathrm{x}_{5}
\end{gathered}
$$

Аналіз рівняння регресії показує, що із збільшенням кількості цукру пудри в складі таблеток «Ангіолін» їх стиранність зменшується, а кількості МКЦ 200, натрію кроскармелозии, МКЦ бурст, а також концентрації розчину МЦ 15 - підвищується. Зазначимо, що на даному етапі досліджень стиранність таблеток «Ангіолін» у всіх серіях дослідів була невеликою.

Взаємозв'язок між вивченими фракторами та розпаданням таблеток «Ангіолін» описується наступним рівнянням регресії: $\mathrm{y}_{6}=7,18+0,14 \mathrm{x}_{1}-0,08 \mathrm{x}_{2}+0,97 \mathrm{x}_{3}+1,70 \mathrm{x}_{4}+1,06 \mathrm{x}_{5}$

Аналіз рівняння регресії показав, що із збільшенням кількості МКЦ 200 на стадії опудрення гранул і концентрації розчину МЦ 15 час розпадання отриманих таблеток «Ангіолін» підвищується. Зазначимо, що тільки в досліді № 5 час розпадання отриманих таблеток «Ангіолін» був більшим 10 хв. Із збільшенням кількості МКЦ бурст час розпадання таблеток зменшується, а кількості натрію кроскармелози та цукру пудри - підвищується.

Проведені дослідження показали, що в 5-ти із 8-ми серій дослідів отримали таблетки «Ангіолін» 3 стійкістю до роздавлювання більше $50 \mathrm{H}$ та часом розпадання менше 10 хв. Були проведені додаткові дослідження за схемою «крутого сходження» до оптимуму, в результаті яких запропоновано оптимальний склад таблеток «Ангіолін», наведений в таблиці 3. Таблетки обраного кількісного складу відповідають всім діючим фрармако-технологічним вимогам ДФУ .

Таблетки «Ангіолін» отримували за класичною схемою 3 використанням методу вологої грануляції. Як зв'язуючий розчин використовували $2 \%$ розчин МЦ 15, гранули висушували при температурі $60^{\circ} \mathrm{C}$. На стадії опудрення гранул використовували МКЦ 200 та кальцію стеарат.

Таблиця 3. Склад таблеток «Ангіолін»

\begin{tabular}{|l|c|c|}
\hline \multicolumn{1}{|c|}{ Діюча речовина } & Маса речовини в одній таблетці, г & Вміст речовини в одній таблетці, \% \\
\hline Ангіолін & 0,20000 & 62,5 \\
\hline Цукрова пудра & 0,02560 & 8 \\
\hline МКЦ бурст & 0,02560 & 8 \\
\hline Натрій кроскармелоза & 0,02560 & 8 \\
\hline МКЦ 101 & 0,03296 & 10,3 \\
\hline Розчин МЦ 15, 2\% & $0,03200(0,00064$ сухого) & 0,2 \\
\hline Кальцію стеарат & 0,00320 & 1 \\
\hline МКЦ 200 & 0,00640 & 2 \\
\hline
\end{tabular}

Висновки. 1. Проведено дослідження підбору кількісного вмісту компонентів для отримання таблеток «Ангіолін» методом вологої грануляції.

У результаті проведених додаткових досліджень за схемою «крутого сходження» до оптимуму запропоновано склад таблеток «Ангіолін», який складає ангіолі- ну - 0,2 цукрової пудри - 0,0256, МКЦ бурст - 0,0256, натрій кроскармелози - 0,0256, МКЦ $101-0,0336$, розчин МЦ 15 - 2\%, кальцію стеарата - 0,0032 і МКЦ 200 - 0,0064. Отримані таблетки відповідають усім фрармако-технологічним вимогам ДФУ.

\section{Список літератури}

1. Вибір раціональних допоміжних речовин для створення таблеток «Ангіолін» методом вологої грануляції / О. С. Бідненко, Л. І. Кучеренко, І. А. Мазур [та ін.] // Фармацевтичний часопис. - 2016. - № 2(38). - С. 16-21.

2. Державна Фармакопея України: у 3 томах/ Державне підприємство «Український науковий фрармакопейний центр якості лікарських засобів». - 2-е вид. - Харків : Державне підприємство «Український науковий фрармакопейний центр якості лікарських засобів». - 2016.
3. Компендиум. Лекарственные препараты 2012. / под ред. профр. В. Н. Коваленко. - К. : Морион, 2012. - 2320 с. 4. Корнацький В.М. Серцево-судинна захворюваність в Україні та рекомендації щодо покращання здоров'я в сучасних умовах / В. М. Корнацький, А. П. Дорогой, Т. С. Манойленко // Аналітично-статистичний посібник. - К., 2012. - 117 с.

5. Мазур И. А. Метаболитотропные препараты / И. А. Мазур, И. С. Чекман, И. Ф. Беленичев. - Запорожье, 2007. - 304 c.

ISSN 2312-0967. Фармацевтичний часопис. 2016. № 4 
6. Математичне планування експерименту при проведенні наукових досліджень в фрармації / [Т. А. Грошовий, В. П. Марценюк, Л. І. Кучеренко та ін.]. - Тернопіль : Укрмедкнига, 2008. - 368 с.

7. Подходы к разработке и созданию метаболитотропных препаратов - производных 1,2,4-триазола / И. А. Мазур, И. Ф. Беленичев, Л. И. Кучеренко и др. // Фармаком. - 2012. - № 3. - С. 78-82.

8. Щодо постадійного контролю виробництва таблеток / Л. І. Кучеренко, О. В. Хромильова та ін. // Актуальні
Фармацевтична технологія, біофармація, гомеопатія Pharmaceutical technology, biopharmacy, homeopathy питання фрармацевтичної і медичної науки та практики. - 2014. - № 2. - C. 31-34.

9. Andersson B. Heart rate dependency of cardiac performance in heart failure patients treated / B. Andersson, S. O. Stromblad, F. Waangstein // Eur. Heart. J. - 2009. Vol. 20. - P. $575-580$.

10. Mazur I.A. Selection of disintegrants for wet granulation method of "Angiolin" tablets / Mazur I.A., Kucherenko L.I., Bidnenko O.S. // Запорізький медичний жкрнал. -2016. $-5(98)$. - c. $97-101$.

\title{
ПОДБОР КОЛИЧЕСТВЕННОГО СОСТАВА ВСПОМОГАТЕЛЬНЫХ ВЕЩЕСТВ ПРИ СОЗДАНИИ ТАБЛЕТОК «АНГИОЛИН»
}

\author{
И. А. Мазур ${ }^{1,2}$, Л. И. Кучеренко ${ }^{1,2}$, А. С. Бидненко ${ }^{1}$, Г. И. Ткаченко ${ }^{1,2}$ \\ Запорожский государственный медицинский университет ${ }^{1}$ \\ НПО «Фарматрон», ${ }^{2}$ Запорожье
}

Резюме: статья посвящена подбору количественного состава вспомогательных веществ с целью создания таблеток «Ангиолин» методом влажной грануляции. Изучено влияние 5-ти количественных факторов и с помощью уравнений регрессии первого порядка установлена взаимосвязь между количественными фракторами и устойчивостью к раздавливанию, стираемости и времени распадаемости таблеток «Ангиолин». Предложен оптимальный состав таблеток «Ангиолин».

Ключевые слова: таблетки «Ангиолин», вспомогательные вещества, таблетки, влажная грануляция, количественные фракторы.

\section{SELECTION OF QUANTITATIVE COMPOSITION OF EXCIPIENTS FOR CREATION TABLETS «ANGIOLIN"}

\author{
I. A. Mazur ${ }^{1,2}$, L. I. Kucherenko ${ }^{1,2}$, O. S. Bidnenko ${ }^{1}$, G. I. Tkachenko $0^{1,2}$ \\ Zaporizhzhia State Medical University \\ SPA "Farmatron", Zaporizhzhia
}

Summary: the article is devoted to the selection of the quantitative composition of excipients in order to create tablets "Angiolin" wet granulation method. The effect of 5-quantitative factors and using first-order regression equations of the interrelation between the quantitative factors and resistance to crushing, Abrasion and disintegration time of tablets "Angiolin" was studied. An optimal composition of the tablets "Angiolin" was offered

Key words: angiolin, excipients, tablets, wet granulation, quantitative factors. 